\title{
Siderophile anomalies in the Easter Plume: Source or process?
}

\author{
VALERIE A. FINLAYSON ${ }^{1}$, MANUEL E. SCHILLING ${ }^{2}$, \\ HOPE A. TORNABENE ${ }^{1,3}$, KATHERINE R. $^{2}$ \\ BERMINGHAM $^{3}$, JAMES M. D. DAY ${ }^{4}$ AND RICHARD J. \\ WALKER $^{1}$ \\ ${ }^{1}$ University of Maryland \\ ${ }^{2}$ Universidad Austral de Chile \\ ${ }^{3}$ Rutgers University \\ ${ }^{4}$ Scripps Institution of Oceanography \\ Presenting Author: vfinlays@umd.edu
}

The Easter-Salas y Gomez Hotspot Track, located in the SE Pacific Ocean, likely samples an isolated portion of the Pacific Large Low-Shear Velocity Province. Prior work has characterized its componentry as dominantly FOZO-like, extending to HIMU-like radiogenic $\mathrm{Pb}$ isotopic compositions [1]. The youngest segment of the track shifts to less radiogenic $\mathrm{Pb}$ values as a result of plume-ridge interaction, presenting an opportunity to characterize highly and moderately siderophile compositions of, and processes affecting, mantle reservoirs sampled by a plume [2].

Herein, we present new highly siderophile element abundances (HSE), Re-Os isotopic systematics, and ${ }^{182} \mathrm{~W} /{ }^{184} \mathrm{~W}$ data for Easter Hotspot lavas. A suite from Rapa Nui (Easter Island) samples the range of ages and compositions found among the subaerial main shield and later stages of volcanic activity. Additional submarine basaltic samples dredged from other Easter-Salas y Gomez seamounts represent the long-lived isotopic range expressed within the track, which provide additional information about long-term siderophile element systematics and sources in the plume.

We find that Rapa Nui lavas have among the lowest HSE abundances yet observed in basaltic rocks. They also carry a small-to-unresolvable negative ${ }^{182} \mathrm{~W}$ anomaly $\left(\mu^{182} \mathrm{~W}=-3\right.$ to -6$)$. Anomalous $\mathrm{W}$ may be diluted by plume-ridge interaction, evidenced by elevated $\mathrm{W}$ concentrations in some melts (up to $357 \mathrm{ppb}$ at $<50 \mathrm{wt} . \% \mathrm{SiO}_{2}$ ), but that does not explain unusually low HSE. Highly siderophile element abundances are strongly affected by: 1) melt degree, 2) sulfide saturation, and 3) source composition. We evaluate the interplay of these three factors, both within the source components of Rapa Nui and throughout the Easter-Salas y Gomez track, to further understanding of lower mantle siderophile systematics, plume melting, and distribution of early-differentiated vs. late-accreted material in the solid Earth. [1] Ray et al. (2012), 10.1093/petrology/egs021 [2] Kingsley et al. (2007), 10.1029/2006GC001401 